\title{
Energy efficiency and environmental impact of biogas utilization in landfills
}

\author{
*E. S. Karapidakis; A. A. Tsave; P. M. Soupios; Y. A. Katsigiannis \\ Department of Natural Resources and Environment, Technological Educational Institute of Crete, \\ Chania, 73133, Greece \\ Received 13 January 2010; revised 11 March 2010; accepted 20 May 2010; availaEOHonline 1 June 2010
}

\begin{abstract}
This study investigates the utilization of landfill biogas as a fuel for electrical power generation. Landfills can be regarded as conversion biogas plants to electricity, not only covering internal consumptions of the facility but contributing in the power grid as well. A landfill gas plant consists of a recovery and a production system. The recovery of landfill gas is an area of vital interest since it combines both alternative energy production and reduction of environmental impact through reduction of methane and carbon dioxide, two of the main greenhouse gases emissions. This study follows two main objectives. First, to determine whether active extraction of landfill gas in the examined municipal solid waste sites would produce adequate electric power for utilisation and grid connection and second, to estimate the reduction of sequential greenhouse gases emissions. However, in order to optimize the designing of a plant fed by biogas, it is necessary to quantify biogas production over several years. The investigation results of energy efficiency and environmental impact of biogas utilization in landfills are considering satisfactory enough both in electric energy production and in contribution to greenhouse gases mitigation.
\end{abstract}

Keywords: Electrical power; Energy recovery; Landfill biogas; Methane

\section{INTRODUCTION}

The interest for landfill gas (LFG) recovery for use as an energy resource has increased as a consequence to the conventional resource limitations and significant worldwide environmental problems. The utilization of the appraised recuperated biogas in the municipal solid waste (MSW) sites considered as an effective processes not only for treating organic wastes, but providing at the same time a significant amount of electric power (Taleghani and Shabani Kia, 2004), while since wastes are continuously produced, MSW could be considered as a renewable source of energy (McKendry, 2002). The chemical process that converts wastes of MSW into LFG is known as waste decomposition or degradation. Anaerobic digestion is an environmentally friendly method of waste reduction and energy recovery (Bove and Lunghi, 2006; Tsai and Chou, 2006; Tsai, 2007). Landfill gas is generated under both aerobic and anaerobic conditions. Aerobic conditions occur immediately after waste disposal due to entrapped atmospheric air. The initial aerobic phase is short-lived and produces a gas mostly composed of carbon dioxide.

*Corresponding Author Email: karapidakis@chania.teicrete.gr Tel.: +3028 2102 3076; Fax: +3028 21023003
Since oxygen is rapidly depleted, a long-term degradation continues under anaerobic conditions, thus producing a gas with a significant energy value that is typically $55 \%$ methane $\left(\mathrm{CH}_{4}\right)$ and $45 \%$ carbon dioxide $\left(\mathrm{CO}_{2}\right)$ with trace concentrations of other gases (Zamorano et al., 2007). Generally, production and quality of the biogas were practically constant at $183.7 \mathrm{~mL} / \mathrm{g}$ of volatile solids and the best biogas composition was $73.6 \% \mathrm{CH}_{4}$ and $26.4 \% \mathrm{CO}_{2}$ (Francese et al., 2000). It is also possible to upgrade the landfill gas to a nearly $100 \%$ methane content, after which it can be distributed with natural gas (Willumsen, 1990; Babel et al., 2009). The above mentioned process is influenced by several factors, such as temperature, moisture content, waste composition and diversity of substrates for microbial degradation (Manna et al. 1999; Suthar and Sing, 2008). The use of biogas as a fuel source is environmentally sound because it contributes to a reduction of fossil fuel use and mitigates the greenhouse effect. In particular, the emissions of $\mathrm{CH}_{4}$, one of the two greenhouse gases emitted, are almost 21 times more dangerous than carbon dioxide for the greenhouse effect (Desideri et al., 2003). Because of its multiple benefits, including energy 


\section{E. S. Karapidakis et al.}

generation, pollution removal and other economic, social and ecological advantages, biogas technology has been intensively investigated and more widely implemented. Using landfill gas as an energy resource can help to reduce landfill methane emissions and to reduce dependence on fossil fuel sources of energy, (Yelda and Parikh, 2002). Landfill gas use for power generation is now a near-commercial technology, as it represents a certain amount of energy resource and can cover a certain percentage of energy demand. Nowadays, several landfill gas exploitation projects have been identified worldwide, most of them in the United States and in Europe. Landfills can be regarded as conversion biogas plants to electricity, not only covering internal consumptions of the facility but contributing in the power grid, as well. A landfill gas plant consists of a recovery and a production system (Ogundiran and Afolabi, 2008). Biogas is pumped from vertical wells (perforated piping in bulk of waste) and guided in well stations by horizontal pipes that connect each well with one well station. In well stations, biogas is rounded up and transmitted by primary horizontal network in the electric power station (Desideri et al., 2003; Ravena and Gregersenb, 2007). There, biogas is passed through appropriate equipment of dehumidification and elaboration (e.g. freeze) and after is supplied in the generator unit for combustion and electric power production (Panjeshahi and Ataei, 2008). The objective of this study is first to determine whether active extraction of landfill gas in the examined municipal solid waste sites would produce adequate electric power for utilisation and grid connection, and second to estimate the reduction of sequential GHGs emissions. However, in order to optimize the designing of a plant fed by biogas it is necessary to quantify biogas production over several years. A mathematical model "landfill gas emissions model" (LandGEM) for the estimation of biogas generation in the under investigation landfill was applied. As well, an experimental procedure in a municipal solid waste site in Iraklio (Crete Island) was implemented in order to foresee a possible electric power production.

\section{$0 \$ 7$ ( 5,\$/ 6\$1' [0 (7+2' 6}

Waste disposal represents an important problem in developed countries. Many different techniques are available to reduce the amount of waste production and the environmental damage, catering in the energy demand. Various systems via anaerobic degradation of biomass accomplish biogas production and hence electric energy.

In fact such systems exist in most wastewater treatment plants all over the world (Tsagarakis and Papadogiannis, 2006). Another technology of biogas production is applied in cane sugar industry, where biomass is gasified in order to provide combined heat and power. Using this system, the roughly 400 tones of fibre produced per day could be utilized to generate 22 MW, for export, an efficiency of $22 \%$ (Turn et al., 2002).

As well, in a tea industry an extraction of organic matter from the spent tea leaves in the form of leachates was implemented. The generated biogas is utilized by the industry for thermal or electrical applications (Goel et al., 2001).

Biogas technology offers a very attractive route to utilize certain categories of biomass for meeting partial energy needs. Biogas from water hyacinth (Eichhornia crassipes) and channel grass (Vallisneria spiralis) used for phytoremediation of industrial effluents is produced (Singhal and Rai, 2003). Moreover, biogas can be produced from livestock manures and agricultural wastes with a considered energy potential (Al-Masri, 2001). In India, there are an estimated over 250 million cattle and if one third of the dung produced annually from these is available for production of biogas, more than 12 million biogas plants can be installed (Kashyap et al. 2003).

A particular biomass to energy system is represented by landfills. The facility design is based on a demonstrated successful conversion technology in order to ensure quality biogas generation. In most landfills, the refuse deposit usually has a high content of organic matter consisting of a mixture of household, industrial and garden waste. Immediately after the refuse has been placed in the landfill, aerobic decomposition of the organic waste begins. Once the oxygen has been exhausted, anaerobic decomposition is taken place. Biogas which has a methane content of approximately $50 \%$ and can be used as a fuel is produced. A landfill gas plant consists of a recovery system and a production system. A recovery system can consist of vertical perforated pipe wells, horizontal perforated pipes or ditches, or membrane covers to collect the generated gas. The biogas energy potential can be very interesting and it is possible to exploit it as fuel for energy conversion processes (Willumsen, 1990).

Leachates and biogas are the two pollutant emissions that are characteristic of landfills. Pollution 
linked to leachates is usually avoided by means of natural and/or artificial waterproofing located at the bottom and on the sides of the cell and integrated by means of drain pipes useful to extract the produced leaching waters (Manna et al., 1999). Utilization of biogas instead, environmentally sound eliminates the emission of $\mathrm{CH}_{4}$, one of the two greenhouse gases emitted which is about 20 times more dangerous than carbon dioxide for the greenhouse effect (Desider $e t$ al., 2003).

\section{Case studies}

In this study, two different landfills located at city of Volos and city of Heraklion are considered to estimate the utilization potential of generated LFG.

\section{First case}

The landfill is located in Volos (central Greece). It has been operating since 1982 and is estimated that it contains about 1,680,000 tons of waste (annual quantity of waste disposal: 70,000 tons). Except for town refuse, the sludge of wastewater treatment plant is disposed as well. The total capacity of the landfill is approximately $170,000 \mathrm{~m}^{2}$, from which about $90,000 \mathrm{~m}^{2}$ are full filled and the rest of them function till now. From the 90,000 full filled $\mathrm{m}^{2}$ of the landfill, the $50,000 \mathrm{~m}^{2}$ are reconstructed and incorporate a biogas collection network, the other $40,000 \mathrm{~m}^{2}$ are going to be reconstructed directly. The landfill gas collection focuses on contributing to the distribution network and thus reducing the cost for electricity demands in the facility. Biogas is pumped from vertical wells (perforated piping in bulk of waste) and guided in well stations by horizontal pipes that connect each well with one well station. In well stations, biogas is rounded up and transmitted by primary horizontal network in the electric power station. There, biogas is passed through appropriate equipment of dehumidification and elaboration (e.g. freeze) and after is supplied in the generator unit for combustion and electricity power production. Moreover, the plant is equipped with a flare for burning the biogas when the generator is not in operation.

\section{First case landfill gas generation}

Landfill gas generation is generated by degradation of biodegradable fraction and is influenced by physicochemical composition of waste and environmental variables. LFG is composed of approximately equal parts of methane and carbon dioxide with trace concentrations of other gases.

The rate of biogas production or recovery depends on the generation and transport rates of the individual gases generated during the decomposition of organic refuse deposit as well as masses of parameters that define the conditions of decomposition, such as age and constitution of waste, temperature, humidity, phvaries with depth of filling, population of microbes, quality and quantity of alimentary substances, (Findikakis et al., 1988; Kumar et al., 2004; Nwuche and Ugoji, 2008).

The usual way of appraising the rate of volatile organic compounds (VOCs) is by the use of a first order kinetic equation, which is expressed mathematically (Wang Jenshi and Chou, 2000) as:

$$
\frac{d C}{d t}=-k C
$$

Where:

$\mathrm{C}$, is VOCs concentration

$\mathrm{k}$, is rate constant

Under practical conditions in a waste repository, the VOCs concentration is in equilibrium that means the rate of VOCs production equals the rate of decay. The term is used in radioactive decay and first order chemical kinetics. If the rate of change of a quantity is proportional to the amount (or concentration) remaining, as in first order kinetic Eq. 1. Including the above kinetic equation and empirical data, a mathematical model "landfill gas emissions model" (LandGEM) version 3.02 has been designed under the supervision of EPA (Environmental Protection Agency, «municipal solid waste landfills», Vol. 1: Summary of the Requirements for the new source performance standards and emission guidelines for municipal solid waste landfills, EPA-453/R-96-004, Research Triangle Park, NC. U.S. Environmental Protection Agency, Office of Air Quality Planning and Standards). Land GEM is an automated tool for estimating emission rates for total landfill gas, methane, carbon dioxide, nonmethane organic compounds (NMOCs) and individual air pollutants from MSW landfills. The model can be run using site specific data for the parameters needed to estimate emissions or, if no site-specific data are available, using default values. There are two sets of default values: 
CAA defaults: The CAA defaults are based on requirements for MSW landfills laid out by the Clean Air Act (CAA), including the NSPS/EG and NESHAP. This set of default parameters yields conservative emission estimates and can be used for determining whether a landfill is subject to the control requirements of the NSPS/EG or NESHAP.

Inventory defaults: With the exception of wet landfill defaults, the inventory defaults are based on emission factors in the U.S. Environmental Protection Agency's (EPA's) Compilation of Air Pollutant Emission Factors (AP-42). This set of defaults yields average emissions and can be used to generate emission estimates for use in emission inventories and air permits in the absence of site-specific test data.

As well, knowledge of the following parameters is required:

- The design capacity of the landfill;

- The amount of refuse in place in the landfill or the annual refuse acceptance rate for the landfill;

- The methane generation rate $(\mathrm{k})$;

- The methane generation capacity $\left(\mathrm{L}_{0}\right)$;

- The concentration of total nonmethane organic compounds and speciated NMOC found in the landfill gas;

- The years the landfill has been in operation;

- Whether the landfill has been used for disposal of hazardous waste (co-disposal).

The empirical method for calculation of biogas production is expressed mathematically (Paraskaki and Lazaridis, 2005):

$L F G=L_{0} R\left(e^{-k c}-e^{-k t}\right)$

Where:

LFG, is total landfill gas generation rate

$\mathrm{L}_{0}$, is methane generation capacity ( $\mathrm{m}^{3} /$ ton)

$\mathrm{R}$,is annual quantity of waste disposal (ton)

$\mathrm{K}$,is methane generation rate (year ${ }^{-1}$ )

$\mathrm{c}$ and $\mathrm{t}$, are the numbers of years since the landfill closed and opened.

The most considerable parameters of the above equation for biogas production are $\mathrm{L}_{0}$ (potential methane generation capacity) and $\mathrm{k}$ (methane generation rate). According to EPA, the parameters $\mathrm{L}_{0}$ and $\mathrm{k}$ were defined as it is presented in Table 1 . Applying the model for biogas production in the landfill of Volos, CAA default values have been taken under consideration as follows :
- $\mathrm{k}=0.05 /$ year;

- $\mathrm{L}_{0}=170 \mathrm{~m}^{3} /$ ton;

- NMOC concentration $=4000 \mathrm{ppmv}$;

- Methane volume content = $50 \%$;

- Average annual waste disposal = 70 ktons.

The landfill has been operated since 1982 (open year) and in 2002 (closure year) the landfill gas plant was installed. According to the Fig. 1, a noticeable increase in $\mathrm{CH}_{4}$ emissions at 22 first years of waste disposal is reported. In 2003, the maximum value appears equal to $927 \mathrm{~m}^{3} / \mathrm{h}$. In Fig. 2, total landfill gas, $\mathrm{CH}_{4}, \mathrm{CO}_{2}$ and NMOC emissions (mg/y) are represented.

Considering EPA regulations for biogas collection and recovery networks, recuperation rate of biogas production is defined between 75-85 \% due to losses of the plant. In the under investigation landfill, the minimum rate $(75 \%)$ was taken into account. Furthermore, $\mathrm{CH}_{4}$ calorific value equal to $4475 \mathrm{kcal} / \mathrm{m}^{3}$ was presupposed. The detailed calculations are represented in the following Table 2. In Fig. 3, the electric power generation of recuperated biogas $(\mathrm{GWh} / \mathrm{y})$ is reported.

\section{Second case study}

The study area which covers an area of about 0.08 $\mathrm{km}^{2}$ is characterized as a Municipal Solid Waste site (MSW), located $20 \mathrm{Km}$ west of Heraklion (region of Fodele). The annual quantity of waste disposal is 100,000 tons and it has functioned since 1985.

According to the experimental procedure a static enclosure technique was placed in ERT\#2, which regards an active section of the landfill where wastes have been pilled up continuously for the past eight years in order to measure landfill gases emissions. The duration of the experimental procedure was $60 \mathrm{~min}$ and air samples (collected by syringes) were analyzed using the gas chromatograph (GC) Agilent 6890N.

Taking under consideration the ever increasing population, as well as the increase in living standard, a regarding increase in wastes is observed. In accordance with the initial and final measurements (after $60 \mathrm{~min}$ ), in ST1 and ST2 an exploitable concentration of $\mathrm{CH}_{4}$ was detected as represented in Figs. 4 and 5.

Table 1: $\mathrm{L}_{0}$ and $\mathrm{k}$ parameters

\begin{tabular}{lll}
\hline & CAA default value & AP-42 default value \\
\cline { 2 - 3 } $\mathrm{L}_{0}$ & $170 \mathrm{~m}^{3} /$ ton & $100 \mathrm{~m}^{3} /$ ton \\
$\mathrm{k}$ & $0,05 / \mathrm{y}$ (non arid region) & $0,04 / \mathrm{y}$ (non-arid \\
$\mathrm{k}$ & $0,02 / \mathrm{y}$ (arid region) & region) \\
\hline
\end{tabular}


LandGEM method was as well employed with CAA default values $\left(k=0.05 / y, L_{0}=170 \mathrm{~m}^{3} /\right.$ ton, NMOC concentration $=$ inventory no or unknown co-disposal 600 ppmv, methane volume content $=50 \%$, average annual waste disposal $=100,000$ tons). According to the applied Fig. 6, a notable increase that reaches at 1,234 $\times 10^{3}$ in 2006 is reported. In Fig. 7, total landfill gas, $\mathrm{CH}_{4}$, and NMOC emissions (mg/y) are represented.

Considering EPA regulations for biogas collection and recovery networks, recuperation rate of biogas production is defined between $75-85 \%$ due to losses of the plant. In the under investigation landfill the minimum rate (75 \%) was taken into account. Furthermore, $\mathrm{CH}_{4}$ calorific value equal to $4475 \mathrm{kcal} / \mathrm{m}^{3}$ was presupposed. The detailed calculations are represented in the following Table 2. In Fig. 3, the electric power generation of recuperated biogas $(\mathrm{GWh} / \mathrm{y})$ is reported.

\section{Second case sudy}

The study area which covers an area of about 0.08 $\mathrm{km}^{2}$ is characterized as a municipal solid waste site located $20 \mathrm{Km}$ west of Heraklion (region of Fodele). The annual quantity of waste disposal is 100,000 tons and it has functioned since 1985.

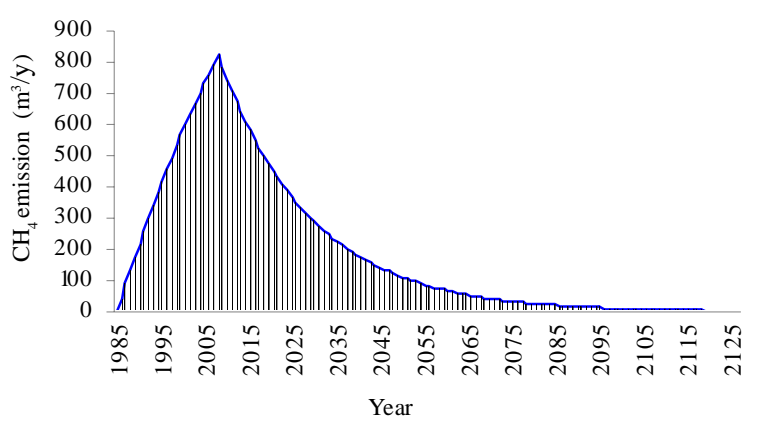

Fig. 1: $\mathrm{CH}_{4}$ emissions $\left(\mathrm{m}^{3} / \mathrm{h} / \mathrm{y}\right)$

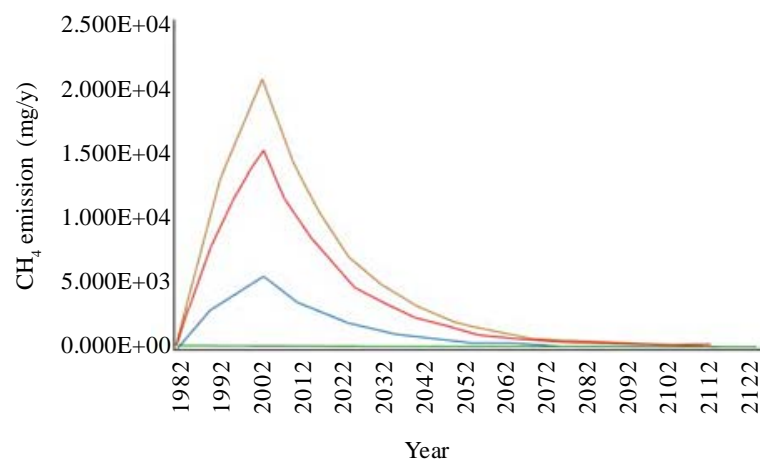

Fig. 2: Landfill gases emissions (mg/y)
According to the experimental procedure, a static enclosure technique was placed in ERT\#2, which regards an active section of the landfill where wastes have been pilled up continuously for the past eight years in order to measure landfill gases emissions. The duration of the experimental procedure was $60 \mathrm{~min}$ and air samples (collected by syringes) were analyzed using the gas chromatograph Agilent 6890N.

Taking under consideration the ever increasing population, as well as the increase in living standard, a regarding increase in wastes is observed. In accordance with the initial and final measurements (after $60 \mathrm{~min}$ ), in ST1 and ST2 an exploitable concentration of $\mathrm{CH}_{4}$ was detected as represented in Figs. 4 and 5.

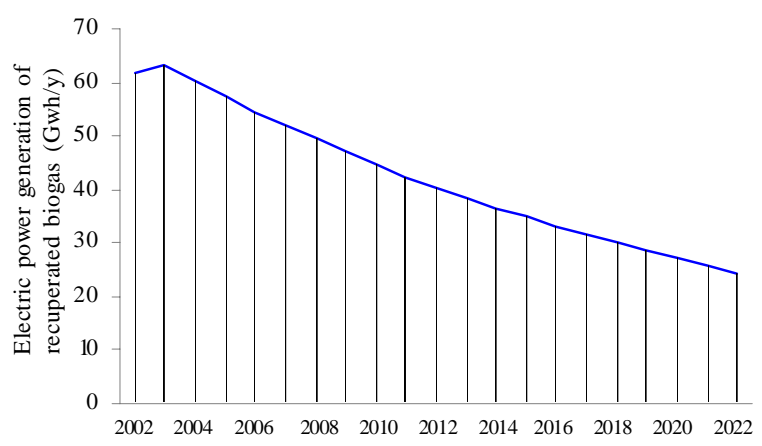

Fig. 3: Electric energy generation per year

Table 2: Appraised recuperated biogas

\begin{tabular}{crrr}
\hline Year & $\begin{array}{c}\text { Biogas } \\
\text { generation } \\
\left(\mathrm{m}^{3} / \mathrm{h}\right)\end{array}$ & $\begin{array}{c}\text { Recuperated } \\
\text { biogas } \\
\left(\mathrm{m}^{3} / \mathrm{h}\right)\end{array}$ & $\begin{array}{c}\text { Power } \\
\text { generation } \\
(\mathrm{GWh} / \mathrm{y})\end{array}$ \\
\hline 2002 & 1799.25 & 1349.44 & 61.51 \\
2003 & 1853.82 & 1390.37 & 63.38 \\
2004 & 1763.41 & 1322.56 & 60.29 \\
2005 & 1677.41 & 1258.06 & 57.35 \\
2006 & 1595.6 & 1196.7 & 54.55 \\
2007 & 1517.78 & 1138.34 & 51.89 \\
2008 & 1443.76 & 1082.82 & 49.36 \\
2009 & 1373.35 & 1030.01 & 46.95 \\
2010 & 1306.37 & 979.78 & 44.66 \\
2011 & 1242.65 & 931.99 & 42.48 \\
2012 & 1182.05 & 886.54 & 40.41 \\
2013 & 1124.4 & 843.3 & 38.44 \\
2014 & 1069.56 & 802.17 & 36.57 \\
2015 & 1017.4 & 763.05 & 34.78 \\
2016 & 967.78 & 725.84 & 33.09 \\
2017 & 920.58 & 690.44 & 31.47 \\
2018 & 875.68 & 656.76 & 29.94 \\
2019 & 832.98 & 624.73 & 28.48 \\
2020 & 792.35 & 594.26 & 27.09 \\
2021 & 753.71 & 565.28 & 25.77 \\
2022 & 716.95 & 537.71 & 24.51 \\
Mean & 1229.85 & 922.39 & 42.04 \\
\hline & & &
\end{tabular}




\section{E. S. Karapidakis et al.}

LandGEM method was as well employed with CAA default values $\left(\mathrm{k}=0.05 / \mathrm{y}, \mathrm{L}_{0}=170 \mathrm{~m}^{3} / \mathrm{ton}, \mathrm{NMOC}=\right.$ inventory no or unknown co-disposal 600 ppmv, methane volume content $=50 \%$, average annual waste disposal $=100,000$ tons). According to the applied Fig. 6, a notable increase that reaches at 1, $234 \times 10^{3}$ in 2006 is reported. In Fig. 7, total landfill gas, $\mathrm{CH}_{4}, \mathrm{CO}_{2}$ and NMOC emissions (mg/y) are represented.

Detailed calculations of the quantity of the recuperated biogas and electric power generation are presented in Table 3 for 21 years long. In Fig. 8, the

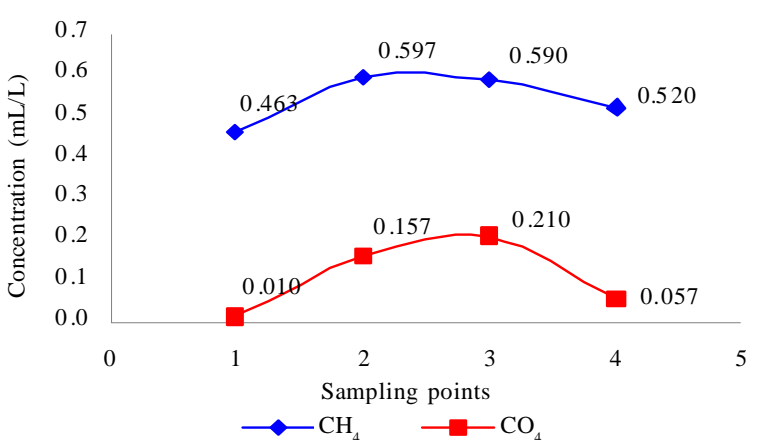

Fig. 4: Initial concentrations of $\mathrm{CH}_{4}-\mathrm{CO}_{2}$

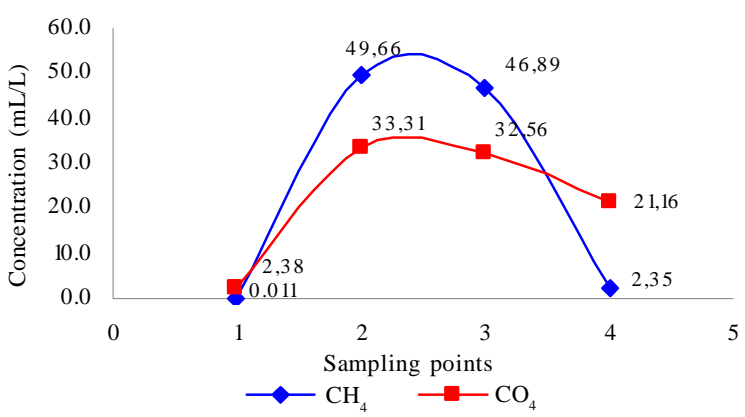

Fig. 5: Final concentrations of $\mathrm{CH}_{4}-\mathrm{CO}_{2}$

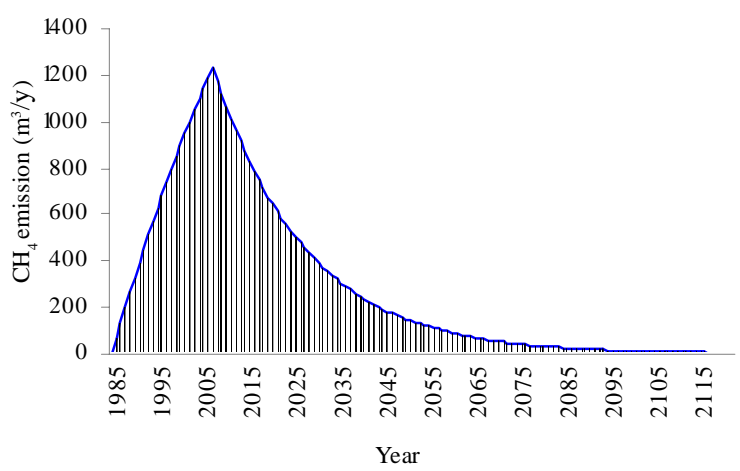

Fig. 6: $\mathrm{CH}_{4}$ emissions $\left(\mathrm{m}^{3} / \mathrm{h} / \mathrm{y}\right)$ electric power generation of the recuperated biogas per year is applied.

\section{5 (68/76\$1' [ , 6\&866,2 1}

Biogas, as a by-product obtained from anaerobic digestion in fermentation of municipal waste in landfill systems (Banu et al., 2007). It can be used for both heat and power generation through combustion procedure. Landfill gas is a valuable energy resource since its total chemical energy is sufficient to sustain the operation of an electric power generator, as a supplementary or primary fuel contributing to the total electric power generation. The combustion of the recuperated landfill biogas is occurred by conversion of methane in carbon dioxide (oxidation), as it is described in the following chemical reaction 3 (Murphy and McKeogh, 2004).

$\mathrm{CH}_{4}+2 \mathrm{O}_{2} \rightarrow \mathrm{CO}_{2}+2 \mathrm{H}_{2} \mathrm{O}$

Biogas at a constant concentration of $50 \% \mathrm{CH}_{4}$ and $50 \% \mathrm{CO}_{2}$ is flammable when its concentration in air is between $9 \%$ and $20 \%$, approximately and it will

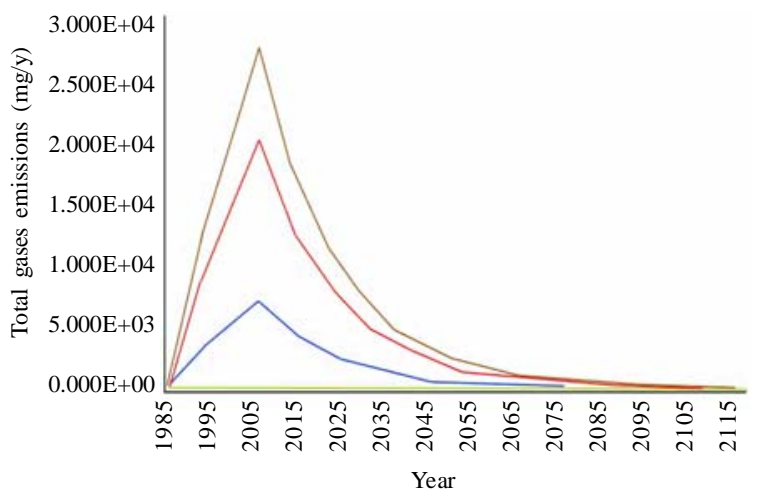

Fig. 7: Landfill gases emissions (mg/y)

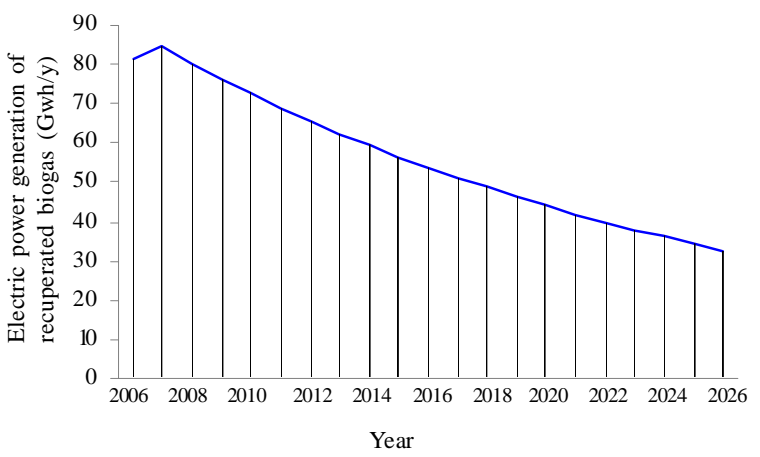

Fig. 8: Electric energy generation 
not bum using a conventional gas combustor if its $\mathrm{CO}_{2}$ concentration is more than $75 \%$ (Constant et al., 1989).

In these cases, new techniques involving heatrecirculating particulate beds such as fluidized bed, spouted bed and crater bed have been introduced in order to overcome the limitations (Malik et al., 1987). The LFG conversion in electric power is implemented by engine/generator system (mostly 1 to $5 \mathrm{MW}$ ) that needs supply of a dried gas, with pressure capacity at least 50 mbar (Augenstein and Pacey, 1992). Thus, power engines must be regulated based on LFG concentration, and basically on methane conciseness.

Generally, landfill gas to electricity technology is established in several countries worldwide. LFG is able to feed the selected engine/generator systems for a steady state operation, in contrury to other renewable energy technologies with undetermined primary source (wind, solar, etc.).

Several surveys of operating and planned LFG recovery projects have been conducted in recent years. Survey results have varied significantly, due to the relatively long project development times, small project sizes, and large number of small developers. In parallel, the general energy market is one of the major factors that influence the viability of LFG recovery. Concluding, LFG electric power generation use one of the categories presented in the following Table 4.

Internal combustion (IC) engines used to generate electricity are most commonly lean fuel burn turbocharged designs that burn fuel with excess air. Less commonly, IC engines may be operating without turbocharging. These engines are less complex, but they have reduced power output and higher emissions. When operated on LFG, engine power ratings are commonly reduced by 5 to 15 percent compared to operation on natural gas. The overall heat rate ranges from 11,000 to 14,000 Btus of LFG per kWh. These IC engines that drive generators to produce electrical power, are specially designed for LFG applications.

Gas turbines used to generate electricity at landfill sites take large quantities of atmospheric air, compress the air, burn fuel to heat the air, and then expand the air in the power turbine to develop power. This power is used to drive electrical generators. Gas turbines should be operated at full capacity to optimize performance and limit operational problems (Weinberg, 1986; Noyola et al., 2006).

Steam-electric turbines are used at several sites where the LFG is burned in a boiler to produce high- pressure steam, which drives a steam turbine to generate electricity. Worldwide, one of the largest LFG recovery project has a nominal capacity up to $50 \mathrm{MW}$ of electric power (Pierce, 2004).

In this study, the operation of two different types of LFG power units; an internal combustion unit and a gas turbine has been examined. The conversion efficiency in each engine/generator system is assumed to be about $25 \%$ to $30 \%$ in total. Additionally, the landfill gas combustion's emissions of each examined power units are presented in Table 5.

Taking into account previous energy capacity of recuperated biogas in $\mathrm{GWh} / \mathrm{y}$, as it is presented in Table 1 and assuming total conversion efficiency in the engine/generator system of $25 \%$, LFG power plant should supply an amount of $20.31 \mathrm{GWh}$ in the first year of its operation. Considering the recorded electric energy capacity of recuperated biogas (GWh/y) and taking into account the technical restrictions (system conversion efficiency), the estimated hourly production of LFG should be able to generate an amount of 1.6 MW

Table 3: Appraised recuperated biogas

\begin{tabular}{cccr}
\hline Year & $\begin{array}{c}\text { Biogas } \\
\text { generation } \\
\left(\mathrm{m}^{3} / \mathrm{h}\right)\end{array}$ & $\begin{array}{c}\text { Recuperated } \\
\text { biogas } \\
\left(\mathrm{m}^{3} / \mathrm{h}\right)\end{array}$ & $\begin{array}{c}\text { Power } \\
\text { generation } \\
(\mathrm{GWh} / \mathrm{y})\end{array}$ \\
\hline 2006 & 2375.63 & 1781.72 & 81.22 \\
2007 & 2468.51 & 1851.38 & 84.39 \\
2008 & 2348.12 & 1761.09 & 80.28 \\
2009 & 2233.60 & 1675.20 & 76.36 \\
2010 & 2124.67 & 1593.50 & 72.64 \\
2011 & 2021.05 & 1515.79 & 69.09 \\
2012 & 1922.48 & 1441.86 & 65.72 \\
2013 & 1828.72 & 1371.54 & 62.52 \\
2014 & 1739.53 & 1304.65 & 59.47 \\
2015 & 1654.69 & 1241.02 & 56.57 \\
2016 & 1573.99 & 1180.49 & 53.81 \\
2017 & 1497.23 & 1122.92 & 51.19 \\
2018 & 1424.21 & 1068.16 & 48.69 \\
2019 & 1354.75 & 1016.06 & 46.31 \\
2020 & 1288.68 & 966.51 & 44.06 \\
2021 & 1225.83 & 919.37 & 41.91 \\
2022 & 1166.04 & 874.53 & 39.86 \\
2023 & 1109.17 & 831.88 & 37.92 \\
2024 & 1055.08 & 791.31 & 36.07 \\
2025 & 1003.62 & 752.72 & 34.31 \\
2026 & 954.68 & 716.01 & 32.64 \\
& 1636.68 & 1227.51 & 55.95 \\
\hline
\end{tabular}

Table 4: LFG electric generation application

\begin{tabular}{ll}
\hline Engine/Generator type & Use \\
\hline Internal combustion engines & Most common \\
Gas turbines & Common \\
Steam turbines & Limited \\
\hline
\end{tabular}


end-use electric power, regarding the average annual energy capacity of the next 20 years. In the following Fig. 9, SHANKEY diagram is used in order to represent the total energy balance of the examined LFG power plant. As it is mentioned in the previous paragraph, regarding the sizing of the under investigation plant, the required installed power capacity must run at maximum 2.5 MW, as depicted in Fig. 10. Aiming at the optimal operation of the plant, both in its short-term and long-term (life-cycle) planning, four gas turbines of 625 $\mathrm{kW}$ were selected for this study due to reliability and security reasons. Records of electrical usage over a oneyear period indicate an average demand of about 365.3 $\mathrm{kW}$, which is lower in winter and higher in summer with peak load demand up to $500 \mathrm{~kW}$ approximately. Therefore, it is estimated that the system would be able to produce enough biogas in order to cover all the internal power consumptions as well as a significant amount of electric energy to the grid (13.98 GWh as depicted in SHANKEY diagram). Landfill gas electricity generation constitutes an environmentally sound eliminating the emission of $\mathrm{CH}_{4}$, one of the two greenhouse gases emitted by convert it to $\mathrm{CO}_{2}$ via combustion. In this study, an environmental assessment of LFG electricity

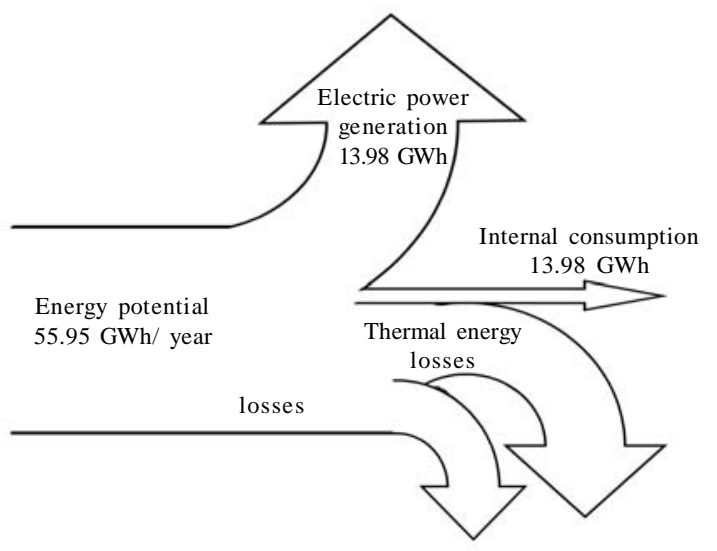

Fig. 9: SHANKEY diagram

Table 5: LFG power units emissions

\begin{tabular}{lcc}
\hline Emission & $\begin{array}{c}\text { Reformed IC } \\
\left(\mathrm{mg} / \mathrm{m}^{3}\right)\end{array}$ & Gas turbine $\left(\mathrm{mg} / \mathrm{m}^{3}\right)$ \\
\hline Particles & 4.3 & 9 \\
$\mathrm{CO}$ & 800 & 14 \\
$\mathrm{HC}$ & 22 & 15 \\
$\mathrm{NOx}$ & 795 & 61 \\
$\mathrm{HCI}$ & 12 & 38 \\
$\mathrm{SO}_{2}$ & 51 & 6 \\
Dioxines & 0.4 & 0.6 \\
Furans & 0.4 & 1.2 \\
\hline
\end{tabular}

generation was accomplished, using 'Long-range energy alternatives planning system’ (LEAP software system, a scenario-based energy-environment modeling tool) and the associated technology and environmental database (TED) in order to estimate the environmental emissions of the energy utilization (Shin et al., 2005). More precisely, the comparison of two scenarios, emissions of crude oil and LFG, respectively as fuel type of power production units was implemented. Both LFG power plant and an equivalent conventional oil-fired power plant have been modeled within the LEAP energy modeling framework to compare their results of greenhouse gas emissions and the corresponding savings potential. The summarized results are presented in the following Table 6.

\section{Environmental impact}

Energy demand must be managed to cope not only with energy but with environmental problems, as well. The energy production from renewable sources is one of the main issues to reduce environmental damage and greenhouse gases emissions, as climate agreements encourage non fossil fuel use in the future.

Landfill gas is a flammable and potentially harmful gaseous mixture consisting mainly of $\mathrm{CH}_{4}$ and $\mathrm{CO}_{2}$ with trace amounts of volatile organic compounds. The air quality deterioration derived from LFG can be controlled by combustion (gas turbines) and chemical cleaning (Borjesson and Berglund, 2006). The calculations of Land GEM for the annual emissions of total LFG, $\mathrm{CH}_{4}$, $\mathrm{CO}_{2}$ and NMOCs in $\mathrm{m}^{3} / \mathrm{y}$ are represented in Fig. 11 . The complete exploitation of LFG for electric energy generation at the examined landfill leads to approximately 4933.86 tons of oil equivalent (TOE) saving and additional increase of 57.9 tons of $\mathrm{CO}_{2}$ reduction.

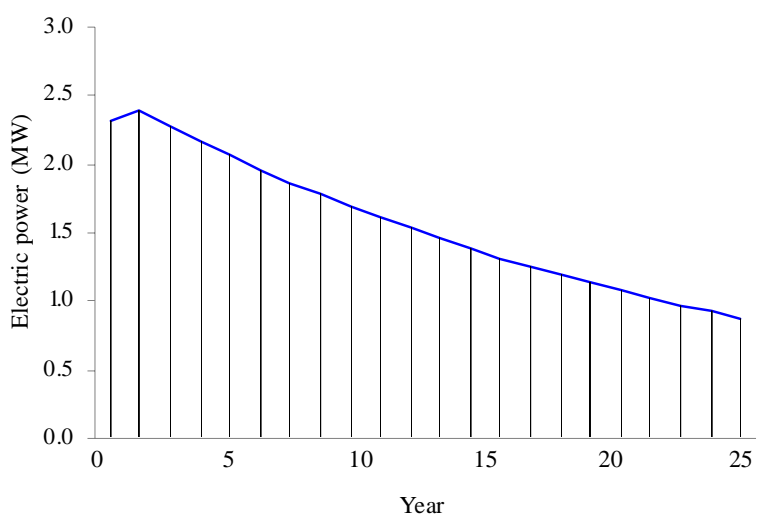

Fig. 10: Appraised power generation per year 
Table 6: LFG and oil emissions

\begin{tabular}{lllll}
\hline $\begin{array}{l}\text { Generation } \\
\text { type }\end{array}$ & $\begin{array}{l}\mathrm{CO}_{2} \\
(\mathrm{tn} / \mathrm{y})\end{array}$ & $\begin{array}{l}\mathrm{CO} \\
(\mathrm{kg} / \mathrm{y})\end{array}$ & $\begin{array}{l}\mathrm{NO}_{\mathrm{x}} \\
(\mathrm{kg} / \mathrm{y})\end{array}$ & $\begin{array}{l}\mathrm{SO}_{2} \\
(\mathrm{~kg} / \mathrm{y})\end{array}$ \\
\hline LFG / IC & 14434 & 8602.39 & 8548.63 & 548.40 \\
LFG / Gas & 9876 & 150.54 & 655.93 & 64.52 \\
Oil - Fired & 57.9 & 5035.5 & 6714 & - \\
\hline
\end{tabular}

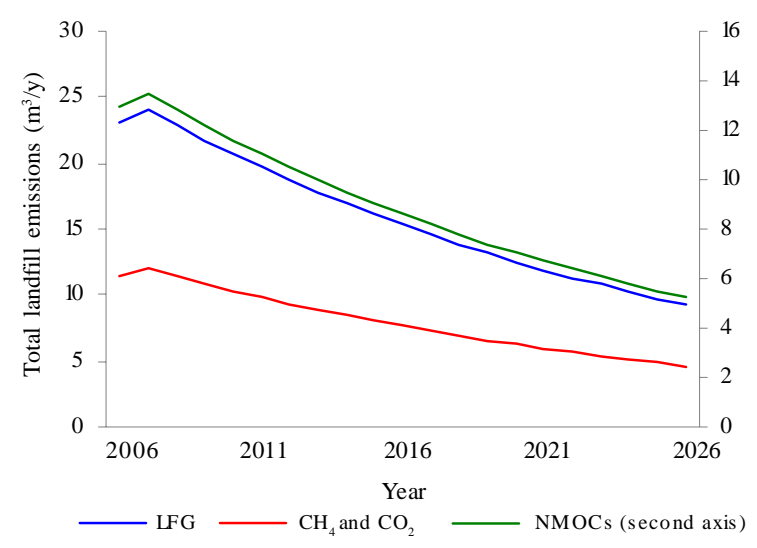

Fig. 11: Landfill emissions

The carbon dioxide released from burning landfill gas is considered to be a part of the natural carbon cycle of the earth. Producing electricity from landfill gas avoids the need to use non-renewable resources to produce the same amount of electricity. In addition, burning landfill gas prevents the release of methane, a potent greenhouse gas, into the atmosphere.

\section{CONCLUSION}

This paper investigates the utilization of landfill biogas as a fuel for electrical power generation. Energy recovery from waste is an area of vital interest since it is a clean, viable and internationally established waste management technology. Not only reduce GHGs emission but reliance on other fuel sources as well.

Under normal conditions, the rate of decomposition, as measured by gas production, reaches a peak within the first 3-6 years of waste deposition and then slowly tapers off, continuing for periods up to 25 years or more (Qin et al., 2001; Spokas et al., 2006).Taking under consideration the results, as they are depicted in previous figures, collection and utilization systems must be installed in the open year of the landfill in order to achieve the increasing peak rates and avoid at the same time the following observed reduction.

Biogas production and electric power generation of the landfills that are examined in this study increases only for one year. This is due to the fact that LFG collection and utilization system was established after almost 20 years of operation. Despite this short time interval of increment, power production is considerable not only for covering biogas plant's consumptions but for flowing enough power to the grid as well.

\section{REFERENCES}

Al-Masri, M. R., (2001). Changes in Biogas production due to different ratios of some animal and agricultural wastes. Bioresour. Tech., 77 (1), 97-100 (4 pages).

Augenstein, D.; Pacey, J., (1992). Landfill gas energy utilization: Technology options and case studies. Prepared by EMCON Associates, San Jose, CA. Prepared for U.S. Environmental Protection Agency, Office of Research and Development. EPA-600/R-92-116. Washington, D.C.

Babel, S.; Sae-Tang, J.; Pecharaply, A., (2009). Anaerobic codigestion of sewage and brewery sludge for biogas production and land application. Int. J. Environ. Sci. Tech., 6 (1), 131140 (10 pages).

Banu, J. R.; Kaliappan, S.; Yeom, I. T., (2007). Treatment of domestic wastewater using upflow anaerobic sludge blanket reactor. Int. J. Environ. Sci. Tech., 4 (3), 363-370 (8 pages).

Borjesson, P.; Berglund, M., (2006). Environmental systems analysis of biogas systems - Part I: Fuel-cycle emissions. Biomass. Bioenerg., 30 (5), 469-485 (17 pages).

Bove, R.; Lunghi. P., (2006). Electric power generation from landfill gas using traditional and innovative technologies. Energ. Convers. Manage., 47 (11-12), 1391-1401 (11 pages).

Constant, M.; Naveau, H.; Ferrero, G.L.; Nyns, E.J., (1989). Biogas end-use in European community. Elsevier Applied Science, London and New York, 345.

Desideri, U.; Di Maria, F.; Leonardi, D.; Proietti S., (2003). Sanitary landfill energetic potential analysis: A real case study. Energ. Convers. Manage., 44 (12), 1969-1981 (13 pages).

Findikakis, A. N.; Papelis, C.; Halvadakis, C. P.; Leckie, J. O., (1988). Modelling gas production in managed sanitary landfills. Waste Manage. Res., 6 (3), 115-123 (9 pages).

Francese, A. P.; Francese1, A. P.; Aboagye-Mathiesen, G.; Olesen, T.; Córdoba, P. R.; Siñeriz, F., (2000). Feeding approaches for biogas production from animal wastes and industrial effluents. World. J. Microb. Biot., 16 (2), 147-150 (4 pages).

Goel, B.; Pant, D.C.; Kishore, V. V. N., (2001). Two-phase anaerobic digestion of spent tea leaves for biogas and manure generation. Bioresour. Tech., 80, 153-156 (4 pages).

Kashyap, D. R.; Dadhich, K. S.; Sharma, S. K., (2003). Biomethanation under Rsychrophilic Conditions: A review. Bioresour. Tech, 87 (2), 147-153 (7 pages).

Kumar, S.; Mondal, A. N.; Gaikwad, S. A.; Devotta, S.; Singh, R. N., (2004). Qualitative assessment of methane emission inventory from municipal solid waste disposal sites: A case study. Atmos. Environ., 38 (29), $4921-4929$ (9 pages).

Malik, T. I.; Weinberg, F. J.; Boden, J. C.; Fuller, J., (1987). Combustion in crater bed. Combust. Flame., 68 (2), 155-165 (11 pages).

Manna, L.; Zanetti, M. C.; Genon, G., (1999). Modelling biogas production at landfill Site. Res. Conserv. Recycl., 26 (1), 114 (14 pages).

McKendry, P., (2002). Energy production from biomass (part 1): Overview of biomass. Bioresour. Tech., 83 (11), 37-46 (10 pages).

Murphy, J. D.; Mc Keogh, E., (2004). Technical, economic and environmental analysis of energy production from 


\section{E. S. Karapidakis et al.}

municipal solid waste. Renew. Energ., 29 (7), 1043-1057 (14 pages).

Noyola, A.; Manuel, J.; Sagastume, M.; Hernández, J. L., (2006). Treatment of biogas produced in anaerobic reactors for domestic wastewater: Odor control and energy/resource Recovery. J. Rev. Environ. Sci. Biotech., 5 (1), 93-114 (22 pages).

Nwuche, C. O.; Ugoji, E. O., (2008). Effects of heavy metal pollution on the soil microbial activity. Int. J. Environ. Sci. Tech., 5 (3), 409-414 (6 pages).

Ogundiran, O. O.; Afolabi, T. A., (2008). Assessment of the physicochemical parameters and heavy metals' toxicity of leachates from municipal solid waste open dumpsite. Int. J. Environ. Sci. Tech., 5 (2), 243-250 (8 pages).

Panjeshahi, M. H.; Ataei, A., (2008). Application of an environmentally optimum cooling water system designin water and energy conservation. Int. J. Environ. Sci. Tech., 5 (2), 251-262 (12 pages).

Paraskaki, I.; Lazaridis, M., (2005). Quantification of landfill emissions to air: A case study of the ano liosia landfill site in the greater Athens area. Waste. Manag. Res., 23 (3), 199208 (10 pages).

Pierce, J., (2004). Development of a $50 \mathrm{MW}$ landfill gas fired power plant at South Korea's largest landfill. SWANA $27^{\text {th. }}$ LFG Conference, March, San Antonio, Texas.

Qin, W.; Egolfopoulos, F. N.; Tsotsis, T. T, (2001). Fundamental and environmental aspects of landfill gas utilization for power generation. Chem. Eng. J., 82 (1-3), 157-172 (16 pages).

Ravena, R. P. J. M.; Gregersenb, K. H., (2007). Biogas plants in Denmark: Successes and setbacks. Renew. Sust. Energ. Rev., 11 (1), 116-132 (17 pages).

Shin, H.; Park, J. W.; Kim, H. S.; Shin, E. S., (2005). Environmental and economic assessment of landfill gas electricity generation in Korea using LEAP model. Energ. Policy., 33 (10), 1261-1270 (10 pages).

Singhal, V.; Rai, J. P. N., (2003). Biogas production from water hyacinth and channel grass used for phytoremedation of industrial effluents. Bioresour. Tech., 86 (3), 221-225 (5 pages).

Spokas, K.; Bogner, J.; Chanton, J. P.; Morcet, M.; Aran, C.; Graff, C.; Moreau-Le Golvan, Y.; Hebe, I., (2006). Methane mass balance at three landfill sites: What is the efficiency of capture by gas collection systems? Waste Manage., 26 (5), 516-525 (10 pages).

Suthar, S.; Singh, S., (2008). Vermicomposting of domestic waste by using two epigeic earthworms (perionyx excavatus and perionyx sansibaricus). Int. J. Environ. Sci. Tech., 5 (1), 99-106 (8 pages).

Taleghani, G.; Shabani Kia, A., (2004). Technical-economical analysis of the saveh viogas power plant. Renew. Energ., 30 (3), 441-446 (6 pages).

Tsagarakis, K.P.; Papadogiannis, C., (2006). Technical and economic evaluation of the biogas utilization for energy production at iraklio municipality, Greece. Energ. Convers. Manage., 47 (7-8), 844-857 (14 pages).

Tsai, W. T., (2007). Bioenergy from landfill gas (LFG) in Taiwan. Renew. Sust. Energ. Rev., 11 (2), 331-344 (14 pages).

Tsai, W. T.; Chou, Y. H., (2006). An overview of renewable energy utilization from municipal solid waste (MSW) incineration in Taiwan. Renew. Sust. Energ. Rev., 10 (5), 491-502 (12 pages).

Turn, S. Q.; Bain, R. L.; Kinoshita, C. M., (2002). Biomass gasification for combined heat and power in the cane sugar industry. Int. Sugar. J., 104 (1242), 268-273 (6 pages).

Wang Jenshi B.; Chou M. Sh., (2000). Kinetics of atalytic oxidation of benzene, n-hexane and emission gas from a refinery oil/water separator over a chromium oxide catalyst. Air. Waste. Manage., 50 (2), 227-233 (7 pages).

Weinberg, F. J., (1986). Combustion in heat-recirculating burners in advance combustion methods. Academic Press, London and New York.

Willumsen, h., (1990). Landfill gas. Res. Conserv. Recycl., 4 (12), 121-133 (13 pages)

Yedla, S.; Parikh K. J., (2002). Development of a purpose built landfill system for the control of methane emissions from municipal solid waste. Waste Manage., 22 (2), 501506 (6 pages).

Zamorano, M.; Ignacio Pérez Pérez, J.; Aguilar Pavés, I.; Ramos, R. A., (2007). Study of the energy potential of the biogas produced by an urban waste landfill in Southern Spain. Renew. Sust. Energ. Rev., 11 (5), 909-922 (14 pages).

\section{AUTHOR (S) BIOSKETCHES}

Karapidakis, E. S., Ph.D., Assistant Professor, Department of Natural Resources and Environment, Technological Educational Institute of Crete, Chania, 73133, Greece. Email: karapidakis@chania.teicrete.gr

Tsave, A. A., M.Sc. Student, Department of Natural Resources and Environment, Technological Educational Institute of Crete, Chania, 73133, Greece. Email: atsave@gmail.com

Soupios, P. M., Ph.D., Associate Professor, Department of Natural Resources and Environment, Technological Educational Institute of Crete, Chania, 73133, Greece. Email: soupios@chania.teicrete.gr

Katsigiannis, Y. A., Ph.D., Lecturer, Department of Natural Resources and Environment, Technological Educational Institute of Crete, Chania, 73133, Greece. Email: katsigiannis@dpem.tuc.gr

How to cite this article: (Harvard style)

Karapidakis, E. S.; Tsave, A. A.; Soupios, P. M.; Katsigiannis, Y. A., (2010). Energy efficiency and environmental impact of biogas utilization in landfills. Int. J. Environ. Sci. Tech., 7 (3), 599-608. 